\title{
MEW GULLS IN NORTHWESTERN MANITOBA
}

PHILIP A. WRIGHT, P.O. Box 914, Lynn Lake, Manitoba. R0B 0W0

The Mew Gull, a bird rarely reported in Manitoba, is a consistent spring visitor to the Lynn Lake area of northwestern Manitoba. I have observed this small gull each year since 1983 during and shortly after spring breakup around Lynn Lake. Figure 1 shows the location of these sightings as well as two other sightings by the author at Vandekerckhove Lake and Snyder Lake. The suspected general breeding range of the Mew Gull in northeastern Saskatchewan and northwestern Manitoba is also shown. ${ }^{2}$

The Mew Gull breeds in southern Yukon, northwestern and coastal British Columbia, MacKenzie region of the Northwest Territories, northern Sas katchewan as far east as southern Reindeer Lake and very locally in the Churchill area of northern Manitoba. ${ }^{2}$
On 29 June 1974 Calvin Cuthbert observed a single Mew Gull on an island in the Manitoba portion of Reindeer Lake. ${ }^{1}$ Herbert W.R. Copland has informed me that, other than the Reindeer Lake sighting and my records, he knows of no additional reports of Mew Gull in northwestern Manitoba (pers. comm.). The species has, however, been reported in several locations in northeastern Saskatchewan as well as at Churchill in northeastern Manitoba. ${ }^{53}$ The field checklist of Manitoba birds lists Mew Gull as occasional in coastal tundra areas and accidental in other habitats in Manitoba. ${ }^{4}$ Although there are no breeding records for this species in northwestern Manitoba, it is reasonable to assume that the breeding range does extend into this region in the vicinity of Reindeer Lake, since it does breed on the Saskatchewan side of the lake.

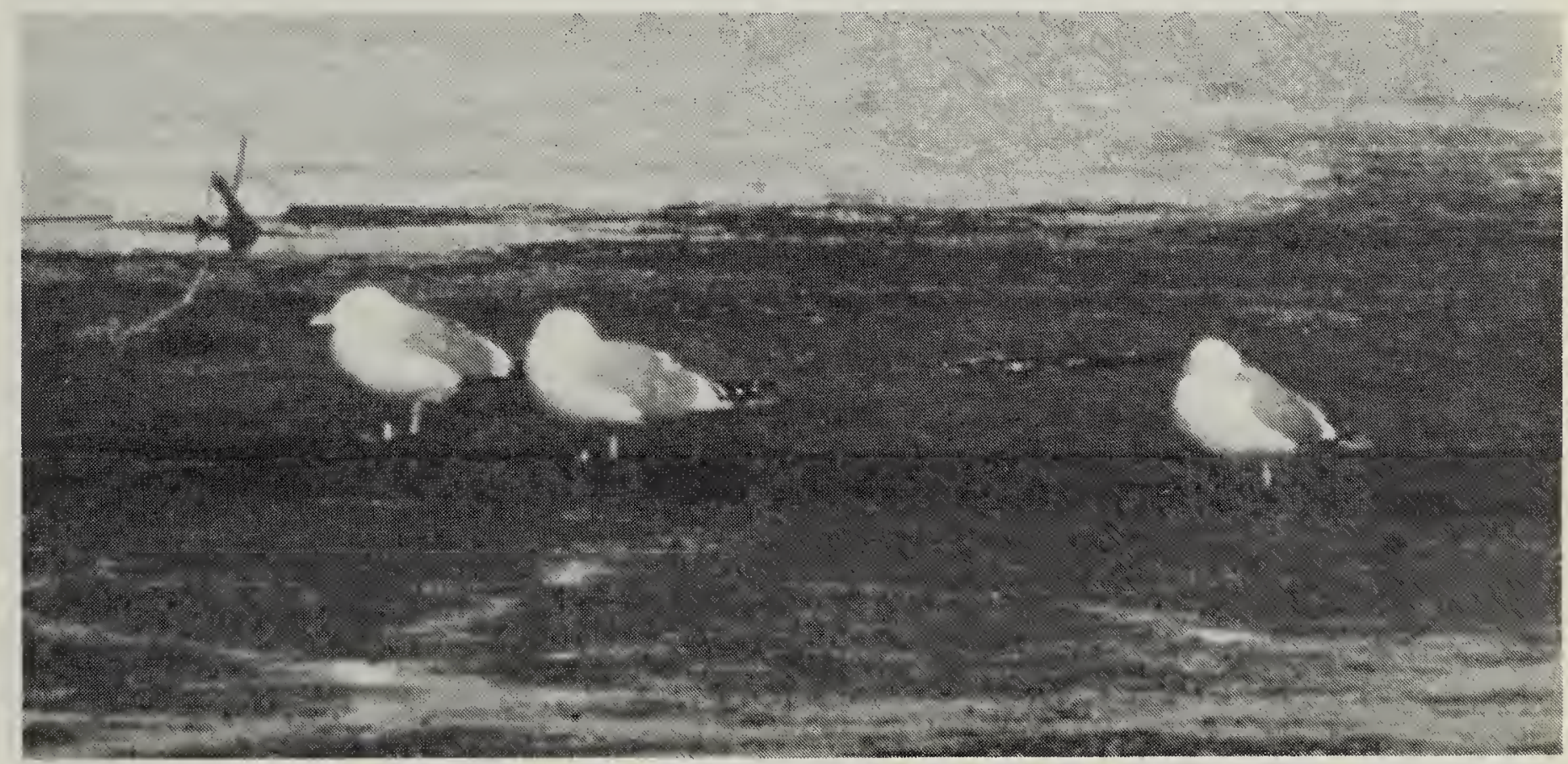


For the past 6 years the Mew Gull has arrived at Lynn Lake just as winter ice is retreating. It has been identified by its small size (slightly smaller than Ringbilled Gull with which it associates and considerably smaller than Herring
Gull), its unmarked, greenish-yellow bill and legs of the same colour and its high-pitched, mew-like call. The species is also somewhat tamer than Ring-billed and Herring gulls. Small groups of 4 to 12 individuals have been

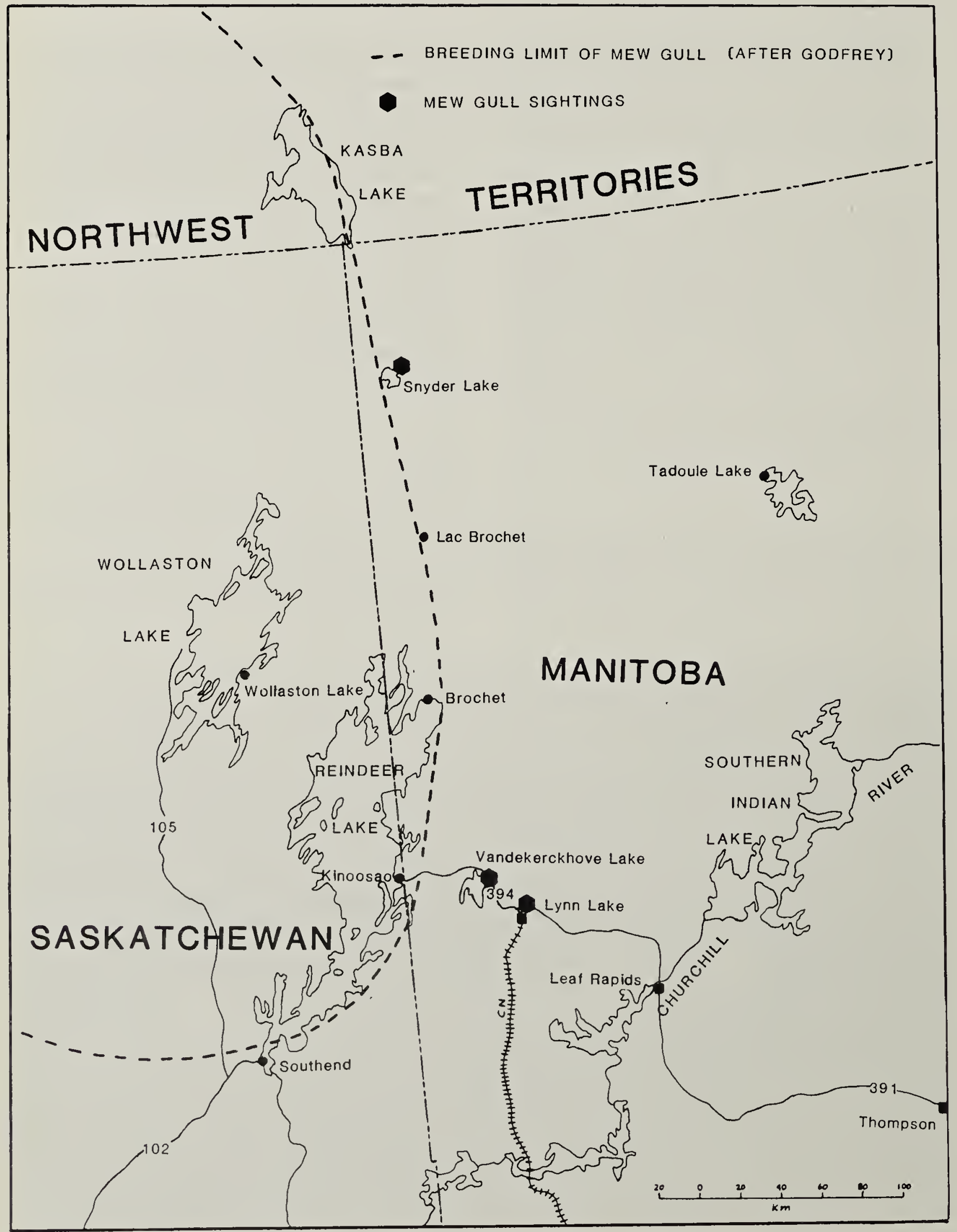

Figure 1. Mew Gull sightings in northwestern Manitoba 
observed for periods of 1-2 weeks in the Lynn Lake area in spring. First sightings range form 20 April (1984) to 21 May (1983).

In 1988 the first Mew Gulls (five) arrived at East Lynn Lake and the Lynn River on 9 May just as open leads in the ice were forming. Up to six individuals were observed over the next 10 days until most of the ice had left. On 16 May 1988 Ian Ripley (local Conservation Officer with the Manitoba Department of Natural Resources) and I sighted five Mew Gulls circling and occasionally alighting on the sewage treatment lagoon at Lynn Lake. The last sighting of the species was on 19 May. By this time most of the ice had gone from local lakes.

Where the Mew Gulls go after leaving Lynn Lake is unknown; they have never been observed in the area during fall migration. However, on 23 May 1987, several Mew Gulls were seen by the author at Vandekerckhove Lake when the suckers were spawning. I also saw a single individual at Snyder Lake on 10 August 1977; this suggests that the species may summer in this area (Fig. 1).

\section{Acknowledgements}

I would like to thank Herbert W.R. Copland of the Manitoba Museum of Man and Nature for encouraging me to write this article and Robert W. Nero, Manitoba Wildlife Branch, for reviewing the manuscript and making helpful suggestions.

'CUTHBERT, C. 1977. Mew gull sighting at Reindeer Lake, Manitoba. Blue Jay 35:47.

${ }^{2}$ GODFREY, W.E. 1986. The birds of Canada, revised edition. Ottawa: National Mus. Can. 595 pp.

${ }^{3}$ JEHL, J.R., Jr. and B.A. SMITH 1970. Birds of the Churchill region, Manitoba. Win nipeg: Man. Mus. of Man and Nature Spec. Publ. 1. 87 pp.

${ }^{4}$ MANITOBA AVIAN RESEARCH COMMITTEE. 1986. Field checklist of the birds of Manitoba. Winnipeg: Man. Mus. of Man and Nature, Man. Naturalists Soc.

${ }^{5}$ NERO, R.W. 1967. The birds of northeastern Saskatchewan. Regina: Sask. Natural Hist. Soc. Spec. Publ. 6. 96 pp.

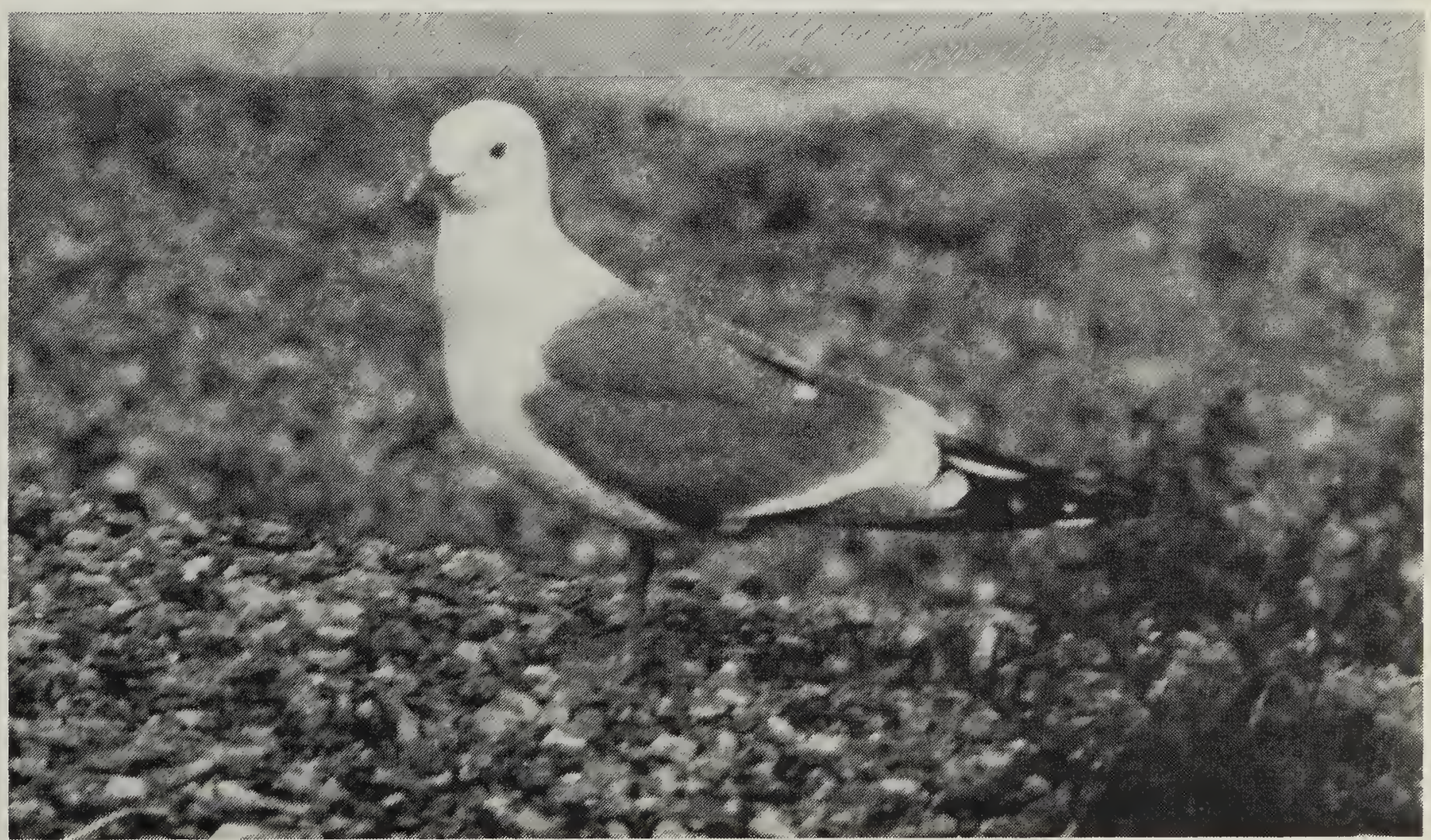

